\title{
Relationship between Competency and Job performance: Based on Empirical Study of R\&D Personnel in Service manufacturing Enterprises
}

\begin{abstract}
Taking R\&D personal as studying object, this paper studies the relationship between competency and job performance empirically. The conclusion shows that R\&D personal's competencies affect its performance positively. All six dimensions have a positive correlation with task performance. Cooperation ability, responsibility and service consciousness positively affect contextual performance.
\end{abstract}

Zhang Ti $^{1}$ Ma Zhiqiang ${ }^{2}$ Zhu Yongyue ${ }^{3}$

${ }^{1,2,3}$ School of Management, Jiangsu University, Zhenjiang, China, 212013 becomes an important trend.
Keywords: Service Manufacturing Enterprises; R\&D Personnel; Competency; Job Performance

\section{Introduction}

With the industrial division of labor and technological development, the external environment of manufacturing enterprises is undergoing significant changes. Product homogeneity competition intensifies. Marginal profit slims. Excessive consumption of resources presents new challenges. The consumer demand shows a knowledge-based, personalized and diversified trend. In this context, domestic manufacturing industry is engaged in a profound change. The value chain expands. Manufacturing enterprises strengthen the competitiveness trough providing services. Service-oriented Manufacturing

Study and practice have proved that the enhanced R\&D capabilities can provide inexhaustible motive for manufacturing enterprises. R\&D competency determines a company's innovation ability and core competitiveness. Compared with traditional manufacturing enterprises, the R\&D work in service manufacturing enterprises is more complex, which puts forward higher demands for $R \& D$ personnel's capability. Therefore, building a competency model, exploring the relationship between competency and job performance has significant theoretical and practical value.

\section{Literature review and hypotheses}

\subsection{Service manufacturing}

Vandermerwe and Rada (1988) first proposed the concept of "Servitization of Manufacturing" and defined it as: manufacturing enterprises change from product providers to products-service packs providers [1]. Szalavetz (2003) believes service-oriented manufacturing has two meanings: First, effective internal service is an important source of competitiveness; Second, product-related service is becoming more and more important to customers ${ }^{[2]}$. In recent years, scholars in China have carried out study and put forward the concept of Service Manufacturing. Sun Linyan (2008) 
believes that manufacturing and service integration is a new industry form. Manufacturing enterprises not only provide products, but also provide customers with services which cover the whole life cycle of products ${ }^{[3]}$. Qi Ershi (2010) believes, the ultimate goal of modern manufacturing industry is to maximize the demand of customers. Service runs through the whole supply chain ${ }^{[4]}$. Trough the joint effort of home and abroad researchers, Service Manufacturing has developed into a mature academic concept.

\subsection{Competency of $R \& D$ personnel}

McClelland proposed the concept of competence in 1973, which triggered a series of related study. Currently, research on R\&D competency has achieved certain results. Rifkin Kenneth I. (1999) defines R\&D manager's key competency as: providing a competitive advantage for the company through technology leadership; regarding R\&D as a strategic business; promoting innovation and mobilizing internal and external resources. Their specific competence indicators include the ability to work, knowledge and skills, personal qualities ${ }^{[5]}$. Xu Fang (2003) believes that the competency model of R\&D manager should include eleven elements. They are influence, customer orientation, teamwork, expertise, analytical thinking, initiation, developing others, selfconfidence, information searching ability, team leadership and conceptual thinking [6]. The competency model proposed by Cao Maoxing and Wang Duanxu includes achievement motivation, conceptual thinking and analytical thinking, teamwork, innovation, expertise and learning ability six elements ${ }^{[7]}$. Zheng Lifeng proposes a six dimension model of R\&D competency. They are achievement motivation, thinking skills, teamwork, innovation, technical expertise and demand sensitivity ${ }^{[8]}$. Through analyzing the $R \& D$ mode of service manufacturing enterprises, this study proposes a six dimension model of $R \& D$ personnel which includes collaboration, responsibility, innovation, service orientation, learning ability and market sensitivity.

\subsection{Relationship between competency and job performance}

Borman and Motowidlo divided job performance into task performance and contextual performance ${ }^{[9]}$. Task performance is directly related with work output. Job content, individual ability, task proficiency and job knowledge are closely related. Contextual performance is not directly related with task but can promote task performance. It includes interpersonal relationships and motivation factors, such as having a good relationship with co-workers, willing to work overtime, solving difficulties actively. This study refers the previous study and divided job performance into task performance and contextual performance two elements.

About the relationship between competency and performance, Holmes and Joyce (1993) points out that when conducting research competence, competency should focus on how it affects their performance and to select those which impact performance ${ }^{[10]}$. Zheng Lifeng (2007) suggests that R\&D competency has a significant positive impact on job performance ${ }^{[1]}$. Zhang Xujuan (2011) also approves that R\&D competency in software outsourcing companies is positively related to outsourcing performance.

Research above shows that competency can provide support for job performance prediction. Based on this, we propose the following hypotheses: 
H1: In service manufacturing companies, R\&D personal's competency have a positive correlation with job performance.

$\mathrm{H} 2$ : In service manufacturing companies, various dimensions of $\mathrm{R} \& \mathrm{D}$ personal's competency have different effects on task performance and contextual performance.

$\mathrm{H} 2 \mathrm{a}-\mathrm{H} 2 \mathrm{f}$ : In service manufacturing companies, $R \& D$ personal's collaboration capability (2a), responsibility (2b), innovation ability (2c), service orientation (2d), learning ability (2e) and market sensitivity (2f) are positively related with their task performance.

$\mathrm{H} 2 \mathrm{~g}-\mathrm{H} 2 \mathrm{l}$ : In service manufacturing companies, $\quad$ R\&D personnel's collaboration capability (2a), responsibility (2b), innovation ability (2c), service orientation (2d), learning ability (2e) and market sensitivity (2f) are positively related with their contextual performance.

\section{Questionnaires and data validation}

\subsection{Questionnaire design}

Referring on domestic and international measuring scales, the design of this questionnaire aims to be in line with the background of service manufacturing. The scale includes collaboration, responsibility, innovation ability, service orientation, learning ability and market sensitivity six evaluation indexes and 26 measuring questions. Performance measurement scale refers to Sun Jianmin and Jiao Changquan's managers working structure questionnaire and is modified accordingly. Five Likert scales are used. Validated by experts, the scale has clear entries and high content validity.

\subsection{Sample Description}

The survey object is $R \& D$ personal from service manufacturing enterprises in the region of Yangtze River Delta. They are from different education level and function level. Questionnaires are distributed by Email. 200 questionnaires were distributed. 163 returned questionnaires are effective. The effective rate is $81.5 \%$.

\subsection{Reliability, validity analysis and correlation analysis}

In this paper, SPSS18.0 statistical software is used for data reliability and validity analysis, using Cronbach' $\alpha$ as scale reliability evaluation. Cronbach' $\alpha$ coefficients of two subscales are both greater than 0.8 , indicating that the questionnaires have good reliability. Further analysis shows that, KMO value $=0.827>0.7$, Bartlett's test of sphericity results significantly ( $\mathrm{p}<0.01$ ), suggesting that each item of the questionnaire is highly correlated. It is suitable for exploratory factor analysis.

In this study, mean of each variable, standard deviation and correlation coefficients are used for cross-correlation analysis. The results are shown in Table 1, from which it can be seen, all elements of R\&D personnel's competency are significantly related with job performance at the level of 0.05 or 0.01 . Initial conclusion can be made that R\&D personnel's competency has a positive correlation with job performance, which verifies the hypothesis of this study. In addition, each sub-dimension of $R \& D$ competency is not completely isolated, but inter-related to each other. Completion of job task needs the integration use of various capacities. 


\begin{tabular}{|c|c|c|c|c|c|c|c|c|c|c|}
\hline Variables & M & SD & 1 & 2 & 3 & 4 & 5 & 6 & 7 & 8 \\
\hline collaboration capability & 3.92 & 0.87 & 1 & & & & & & & \\
\hline responsibility & 3.73 & 0.86 & 0.47 & 1 & & & & & & \\
\hline innovation ability & 3.91 & 0.89 & 0.56 & 0.35 & 1 & & & & & \\
\hline service orientation & 3.95 & 0.81 & 0.45 & 0.31 & 0.39 & 1 & & & & \\
\hline learning ability & 3.86 & 0.88 & 0.51 & 0.42 & 0.37 & 0.21 & 1 & & & \\
\hline market sensitivity & 3.77 & 0.86 & 0.62 & 0.34 & 0.28 & 0.37 & 0.36 & 1 & & \\
\hline Task performance & 3.96 & 0.98 & 0.58 & 0.52 & 0.52 & 0.60 & 0.44 & 0.38 & 1 & \\
\hline Contextual performance & 3.92 & 0.92 & 0.68 & 0.63 & 0.26 & 0.42 & 0.37 & 0.35 & 0.36 & 1 \\
\hline
\end{tabular}

Fig.1: The main variables descriptive statistics and correlation coefficients

\subsection{Regression Analysis}

(1) Regression analysis of $\mathrm{R} \& \mathrm{D}$ competency on task performance

From the regression analysis (Table 2), collaboration, responsibility, innovation, service orientation, learning ability and market sensitivity six dimensions are incorporated into the task performance standard regression equation. The regression equation $\mathrm{F}$ test reaches the .01 level of significance, indicating that the regression effect is significant. Six dimensions explain $46.5 \%$ of the variation of task performance. Further analysis shows that with greater correlation coefficient, comes greater regression coefficient. So the relationship between competency and performance is further verified. Hypotheses $\mathrm{H} 2 \mathrm{a}-\mathrm{H} 2 \mathrm{f}$ are valid.

\begin{tabular}{|c|c|c|c|c|c|}
\hline Factors & $\begin{array}{l}\text { Regression } \\
\text { coefficient }\end{array}$ & $\begin{array}{c}\text { Standard } \\
\text { regression } \\
\text { coefficient }\end{array}$ & $\mathrm{T}$ value & Significance & \multirow{8}{*}{$\begin{array}{c}\mathrm{R}=0.682 \\
\mathrm{R}^{2}=0.465 \\
\text { Adjusted } \mathrm{R}^{2}=0.432 \\
\mathrm{~F}=13.86\end{array}$} \\
\hline Constant & -0.02 & & -0.23 & 0.82 & \\
\hline Collaboration Capability & 0.18 & 0.16 & 2.04 & 0.00 & \\
\hline Responsibility & 0.21 & 0.18 & 2.95 & 0.00 & \\
\hline Innovation Ability & 0.13 & 0.11 & 2.83 & 0.00 & \\
\hline Service Orientation & 0.12 & 0.10 & 1.72 & 0.01 & \\
\hline Learning Ability & 0.14 & 0.11 & 1.68 & 0.00 & \\
\hline Market Sensitivity & 0.12 & 0.09 & 2.13 & 0.02 & \\
\hline
\end{tabular}

Fig.2: Regression analysis of R\&D competency on task performance

(2) Regression analysis of $R \& D$ competency on contextual performance

From the regression analysis (Table 3), collaboration, responsibility and service orientation three dimensions are incorporated into the contextual performance standard regression equation.

\begin{tabular}{|c|c|c|c|c|c|}
\hline Factors & $\begin{array}{l}\text { Regression } \\
\text { coefficient }\end{array}$ & $\begin{array}{c}\text { Standard } \\
\text { regression } \\
\text { coefficient }\end{array}$ & $\mathrm{T}$ value & Significance & $\begin{array}{r}\mathrm{R}=0.609 \\
\mathrm{P}^{2}-0360\end{array}$ \\
\hline Constant & 0.02 & & 0.24 & 0.83 & $K=0.360$ \\
\hline Collaboration Capability & 0.33 & 0.30 & 3.11 & 0.00 & $\begin{array}{c}\text { Adjusted } \mathrm{R}=0.315 \\
\mathrm{~F}=1523\end{array}$ \\
\hline Responsibility & 0.22 & 0.18 & 2.08 & 0.00 & \\
\hline Service Orientation & 0.16 & 0.13 & 1.85 & 0.02 & \\
\hline
\end{tabular}

Fig.3: Regression analysis of R\&D competency on contextual performance 


\section{Results and Discussion}

This paper studies the relationship between R\&D personnel's competency and job performance in service manufacturing enterprises. Regression analysis shows that all six dimensions of competencies go into the task performance standard regression equation. Collaboration, responsibility and service orientation three dimensions are incorporated into the contextual performance standard regression equation. Innovation, learning ability and market sensitivity are not incorporated into the equation. The results have some discrepancies with our hypotheses. Such a situation may be due to these three factors do not directly affect the relationship performance but by other factors. The specific relationship needs further study.

The innovation of this study is that the study is based on the specific background of service manufacturing, which gives the study a certain theoretical value. Its practical significance is that competency model can provide manufacturing enterprises with reference when selection, training and assessing R\&D personals, which will help improve the competencybased human resource management system. Besides, $\mathrm{R} \& \mathrm{D}$ staff can objectively evaluate their own competence, and promote self-learning and growth.

In this study, there are some limitations, mainly as follows: firstly, homologous error problem is inevitable, future research could consider a variety of research methods to reduce the impact of homologous errors. Secondly, questionnaire used has some subjective items. Future research will further improve the existing scale and explain competency differences more in-depth.

ACKNOWLEDGEMENT: Thanks for the support by National Social Science Foundation Youth Project under Grant 11CGL014.

\section{References}

[1]. Vandermerwe S, Rada J. Servilization of business: adding value by adding services[J]. European Management Journal, 1988, 6(4): 314-324.

[2]. Szalavetz A. Servilization of manufacturing industry in the new economy experiences in Hungarian companies[D]. Budapest: Hungarian Academy of Sciences Working Papers, No.134, March 2003.

[3]. Sun Linyan, Gao Jie, Zhu chunyan. Service manufacturing: a new product model and manufacturing paradigm $[\mathrm{J}]$.Chinese Journal of Mechanical Engineering, 2008, 19(21): 2600-2608.

[4]. Qi Ershi, Shi Xuegang, Li Xiaomei. Review on modern service manufacturing $[\mathrm{J}]$.Industrial

Engineering, 2010, 13(5): 1-7.

[5]. Rifkin Kenneth I, Fineman Michal, Ruhnke Clara H. Developing technical managers--first you need a competency model[J]. Research Technology Management, 1999, 3(5): 53-57.

[6]. Xu Fang. Competency model of $\mathrm{R} \& \mathrm{D}$ Team and its influence on team performance $[\mathrm{J}]$.Management Modernizing, 2003 (2): 43-46.

[7]. Cao Maoxing, Wang Duanxu. Research on R\&D personal' $s$ competence $[\mathrm{J}]$.Technoeconomics 
\&Management Rearch, 2006(2): 3840.

[8]. Zheng Lifeng. Relationship among job characteristics, competence and job performance in high-tech entreprises[D].Hangzhou : Zhejiang University, 2007.

[9]. Borman, W. C., et al. Personnel selection in organization. IN: Borman, W.C., Motowidlo, S.J (eds). Expanding the criterion domain to include elements of contextual performance[M]. San Francisco: Joseey-Bass, 1993: 71-98.

[10]. Holmes L, Joyce P. Rescuing the useful concept of managerial competence: from outcomes back to process[J]. Personnel Review, 1993, 22(6): 37-52.

[11]. Zhang Xujuan. Relationship between R\&D competence and outsourcing performance in software outsourcing entreprises[D].Xi'an university of electronic science and technology, 2011.

[12]. Sun Jianmin, Jiao Changquan. Exploratory study managers' working performance[J]. Human Ergonomics, 2002, 8(3):2-10. 